\title{
Effect of Exogenous Progesterone or Flunixin Meglumine After AI on Serum Progesterone Concentration and Pregnancy per AI in Lactating Dairy Cows
}

\author{
Saber Barkhori-Mehni ${ }^{1}$, Hamed Karami-Shabankareh ${ }^{2}$, Reza Masoumi ${ }^{3,9}$, Mehdi Kazemi- Bonchenari ${ }^{4}$, \\ Adel Pezeshki ${ }^{5}$, Arya Badiei ${ }^{6}$, Essa Dirandeh ${ }^{7,9}$, Marcos G. Colazo $^{8}$
${ }^{1}$ Department of Health and Food Safety, Faculty of Veterinary Medicine, Ferdowsi University of Mashhad, Mashhad, Iran.
${ }^{2}$ Department of Animal Science, Faculty of Agriculture, University of Razi, Kermanshah, Iran.
${ }^{3}$ Department of Animal Science, Faculty of Agriculture, University of Zanjan, Zanjan, Iran.
${ }^{4}$ Department of Animal Science, Faculty of Agriculture and Natural Resources, Arak University, Arak, Iran.
${ }^{5}$ Department of Animal Science, Oklahoma State University, Stillwater, United States of America.
${ }^{6}$ Department of Clinical Sciences, Veterinary Faculty, Islamic Azad University, Karaj, Alborz, Iran.
${ }^{7}$ Department of Animal Science, Sari Agricultural Sciences and Natural Resources University, Sari, Iran.
${ }^{8}$ Livestock Research Section, Alberta Agriculture and Forestry, Edmonton, AB, T6H 5T6, Canada.

\begin{abstract}
The objective of this study was to determine the effect of post AI administration of exogenous progesterone $\left(\mathrm{P}_{4}\right)$ or a prostaglandin $\mathrm{F} 2 \alpha(\mathrm{PGF} 2 \alpha)$ synthesis inhibitor agent on serum $\mathrm{P}_{4}$ concentrations and pregnancy per AI (P/AI) in lactating dairy cows. Eighty lactating cows were randomly allocated to one of four treatment groups: 1) CON (control), received $5 \mathrm{~mL}$ of saline solution on d 6 and 14 post AI; 2) IP4 (injection of $\mathrm{P}_{4}$ ), received $125 \mathrm{mg}$ of $\mathrm{P}_{4}$ im on $\mathrm{d} 6$ and 14 post AI; 3) CIDR, received a controlled internal drug release insert containing $1.38 \mathrm{~g}$ of $\mathrm{P}_{4}$ from d 6 to 20 post $\mathrm{AI}$; and 4) FM (Flunixin Meglumine), received $0.625 \mathrm{~g}$ of Flunixin Meglumine, a nonsteroidal anti-inflammatory drug, twice daily on d 15 and 19 post AI. Blood samples were taken on d $0,6,14,17$ and 20 post AI to determine $\mathrm{P}_{4}$ concentrations. Transrectal palpation was performed between 40 and $45 \mathrm{~d}$ post AI to determine pregnancy status. All treatment groups (i.e. IP4, CIDR and FM) resulted in greater serum $\mathrm{P}_{4}$ concentration on $\mathrm{d} 17$ and 20 post AI compared to $\mathrm{CON}(\mathrm{P}<0.05)$. Cows given a CIDR insert had greater concentrations of $\mathrm{P}_{4}$ on $\mathrm{d} 17$ and 20 than IP4 and FM cows $(P<0.05)$. However, no significant difference was found between IP4 and FM groups for serum $\mathrm{P}_{4}$ concentrations. The $\mathrm{P} / \mathrm{AI}$ was greater $(\mathrm{P}<0.05)$ in CIDR-treated cows $(55 \%, 11 / 20)$ than $\operatorname{CON}(25 \%, 5 / 20)$, and intermediate in IP4 $(40 \%$, $8 / 20)$ and FM $(35 \%, 7 / 20)$ cows. In summary, treatment with exogenous $\mathrm{P}_{4}$ (i.e. CIDR and IP4) or FM increased serum $\mathrm{P}_{4}$ concentrations in lactating dairy cows. However, results suggest that only CIDR administration would improve P/AI.
\end{abstract}

Keywords: embryo loss, cattle, progesterone, reproductive performance.

\section{Introduction}

Early embryonic development and establishment of pregnancy in cattle depends upon progesterone $\left(\mathrm{P}_{4}\right)$ secretion by the corpus luteum $(\mathrm{CL}$; Santos et al., 2004; Leroy et al., 2008; Motavalli et al., 2017). Reduced pregnancy per AI (P/AI) in dairy cattle has been associated with low circulating $\mathrm{P}_{4}$ concentrations or a delay in the rise of $\mathrm{P}_{4}$ during the early post ovulatory phase (Mann and Lamming, 1999; Masoumi et al., 2012; Masoumi et al., 2017). Moreover, high producing dairy cows have increased dry matter intake (Holter et al., 1997; Badiei et al., 2014), hepatic blood flow (Sangsritavong et al., 2002), and steroid hormone metabolism resulting in inadequate concentrations of circulating $\mathrm{P}_{4}$. Therefore, various studies have evaluated the effect of supplementation with exogenous $\mathrm{P}_{4}$ during metestrus or early diestrus on fertility of dairy cows, but results have been inconsistent (Larson et al., 2007; Arndt et al., 2009; Friedman et al., 2012; Colazo et al., 2013). In this regard, the efficacy of $\mathrm{P}_{4}$ supplementation post-AI on pregnancy success was recently evaluated in a meta-analysis including 84 treatments involving data from 19,040 cows (Yan et al., 2016). Results showed that $P_{4}$ supplementation from $d 3$ to 7 post-AI was beneficial but supplementation either earlier or later than this period reduced or did not affect P/AI. However, in a recent study, Garcia-Ispierto and López-Gatius (2017) compared pregnancy risk in highproducing lactating dairy cows administered exogenous $\mathrm{P}_{4}$ during metaestrus ( 3 to $5 \mathrm{~d}$ post $\mathrm{AI}$ ) or during the time of pregnancy recognition (15 to $17 \mathrm{~d}$ post-AI) with that in untreated control cows. Cows treated with $\mathrm{P}_{4}$ during metaestrus or during the time of pregnancy recognition were 1.71 and 1.4 times, respectively, most likely to become pregnant than untreated control cows. In cattle, the regression of the CL (luteolysis) is initiated by the release of uterine prostaglandin $\mathrm{F}_{2} \alpha\left(\mathrm{PGF}_{2} \alpha\right)$ at the late luteal stage (McCracken et al., 1999; Masoumi et al., 2011). Hence, other studies have attempted to extend the life-span of the CL with the administration of agents that inhibit the synthesis or release of $\mathrm{PGF}_{2} \alpha$ to enhance pregnancy in cattle (Elli et al., 2001; Geary et al., 2010). In this regard, greater P/AI was obtained in Italian Friesian cattle treated with ibuprofen lysinate, a Cyclooxygenase 1 and 2 (COX-1 and COX-2) inhibitor on d 17 after AI (Elli et al., 2001). Flunixin Meglumine (FM), a strong non-steroid anti-inflammatory drug (NSAID), also prevents the synthesis of COXs and conversion of arachidonic acid to $\mathrm{PGF}_{2} \alpha$ (Purcell et al., 2005; Geary et al., 2010). Although, Anderson et al. (1986) reported that FM could potentially extend the life-span of the CL in lactating dairy cows, there is a 
lack of publications about the effect of FM on serum concentration of $\mathrm{P}_{4}$ and $\mathrm{P} / \mathrm{AI}$.

The primary objective of this study was to evaluate the effect of post AI administration of exogenous $\mathrm{P}_{4}$ or a $\mathrm{PGF}_{2} \alpha$ synthesis inhibitor agent on serum $\mathrm{P}_{4}$ concentrations in lactating dairy cows. A secondary objective was to determine whether post AI administration of exogenous $\mathrm{P}_{4}$ or a $\mathrm{PGF}_{2} \alpha$ synthesis inhibitor agent would improve P/AI. Our hypothesis was that post $\mathrm{AI}$ administration of exogenous $\mathrm{P}_{4}$ or a $\mathrm{PGF}_{2} \alpha$ synthesis inhibitor agent would increase serum $\mathrm{P}_{4}$ concentrations and the proportion of cows becoming pregnant after AI.

\section{Material and methods}

This study was carried out on a commercial dairy farm located near Kermanshah, Iran. All animal experimental procedures were reviewed and approved by the Iranian Ministry of Agriculture (experimental permission No. 3548). Eighty multiparous Holstein dairy cows (Mean \pm SEM; body weight: $652 \pm 22 \mathrm{Kg}$; days in milk: $83 \pm 15$, milk production $29.8 \pm 1.6 \mathrm{~L} / \mathrm{d}$; parity: $3.34 \pm 0.58$, body condition score: $2.84 \pm 0.26$ ) were used in the present study. Cows were fed a TMR (Total Mixed Ration) formulated for a lactating dairy cow of $650 \mathrm{~kg}$ body weight, producing $35 \mathrm{~kg}$ of $3.5 \%$ fat milk per day, according to NRC (2001). The TMR was offered thrice daily and cows had free access to water. Estrus detection was performed by two technicians every $3 \mathrm{~h}$ for at least 20 min during each observation. Estrus was confirmed by transrectal palpation before AI as previously described (LópezGatius and Camón-Urgel, 1991; Masoumi et al., 2018). Cows confirmed in estrus were inseminated, according to the am/pm rule, with semen from sires available commercially. All cows were inseminated by the same technician. Pregnancy status was determined by transrectal palpation performed between 40 and $45 \mathrm{~d}$ post AI.

The day of AI was considered as day 0 of the study and cows ( $n=20$ /group) were randomly allocated to one of four treatment groups (i.e. CON, IP4, CIDR and FM). Cows in the $\mathrm{CON}$ group received $5 \mathrm{~mL}$ of saline solution on $\mathrm{d} 6$ and 14 post AI. Cows in IP4 group received $125 \mathrm{mg}$ of $\mathrm{P}_{4}\left(25 \mathrm{mg} / \mathrm{mL} \mathrm{P}_{4}\right.$, Aburaihan Pharmaceutical Co., Tehran, Iran) on $\mathrm{d} 6$ and 14 post AI. Cows in the CIDR group received a controlled internal drug release insert containing $1.38 \mathrm{~g}$ of $\mathrm{P}_{4}$ (EAZI-BREED CIDR, Zoetis Inc., Dublin, Ireland) from d 6 to 20 post AI. Cows in the FM group received $0.625 \mathrm{~g}$ of Flunixin Meglumine $(50 \mathrm{mg} / \mathrm{mL}$, Banamine, Merck Animal Health, Darmstadt, Germany) twice daily on d 15 and 19 post AI. All treatments were carried out at approximately $0007 \mathrm{~h}$.

Blood samples $(\sim 10 \mathrm{~mL})$ were collected from coccygeal vein into evacuated tubes (Vacutainer ${ }^{\circledR}$; Becton Dickinson and Company, New Jersey, USA) on d $0,6,14,17$ and 20 post AI in all cows approximately at $1100 \mathrm{~h}$. Blood samples were left undisturbed for approximately $2 \mathrm{~h}$ at room temperature to allow clot formation and then centrifuged at $2000 \times \mathrm{g}$ for $10 \mathrm{~min}$, serum harvested and frozen at $-20^{\circ} \mathrm{C}$ until assayed for $\mathrm{P}_{4}$. The serum $\mathrm{P}_{4}$ concentration was determined using a commercial ELISA kit (DRG, Marburg, Germany; EIA1292) as described previously (Heidari et al., 2017; Masoumi et al., 2017). The sensitivity of assay was 0.2 $\mathrm{ng} / \mathrm{mL}$ and the inter- and intra-assay coefficients of variation for samples were 10.2 and $8.3 \%$, respectively. The inter- and intra-assay coefficients of variation for control values were 2.2 and $3.0 \%$, respectively.

Illustration of experimental procedures and treatments during the study are shown in Figure 1.

Data were analyzed using SAS software (SAS 9.3; 2003; SAS Institute Inc., Cary, NC, USA). A probability of 0.05 or less was considered statistically significant, and a probability between 0.051 and 0.1 was considered a tendency.

Serum $\mathrm{P}_{4}$ data was analyzed with the MIXED procedure of SAS using the following model:

$$
Y_{i j k}=\mu+C_{i}+T_{j}+D_{k}+T D_{j k}+\varepsilon_{i j}
$$

Where $Y_{i j}$ is the dependent variable, $\mu$ is the overall mean, $C_{i}$ is the effect of cow $i, T_{j}$ is the effect of treatment $j, D_{k}$ is the effect of sampling day $k$, $T D_{j k}$ is the interaction between treatment $j$ and sampling day $k$ and $\varepsilon_{i j}$ is the residual error. Two orthogonal contrasts were planned a priori to determine the differences between treatment groups (Contrast 1; FM vs. IP4 and CIDR and Contrast 2; IP4 vs. CIDR). Pregnancy per AI (P/AI) was compared among all experimental groups by using logistic procedure of SAS.

\section{Results}

The serum P4 concentrations in all cows during the entire study are presented and displayed in Table 1 and Figure 2. Serum $\mathrm{P}_{4}$ concentrations at $\mathrm{d} 0$ and 6 post AI did not differ $(\mathrm{P}>0.05)$ among treatment groups. However, cows in the IP4, CIDR and FM groups tended to have greater $(\mathrm{P}=0.06)$ serum $\mathrm{P}_{4}$ concentration at $\mathrm{d}$ 14 post $\mathrm{AI}$ and had greater $(\mathrm{P}<0.01)$ serum $\mathrm{P}_{4}$ concentration at $\mathrm{d} 17$ and 20 post $\mathrm{AI}$ compared to cows in the CON group. In addition, cows given a CIDR had greater $(\mathrm{P}<0.01)$ concentrations of $\mathrm{P}_{4}$ in serum at $\mathrm{d} 17$ and 20 post AI than IP4- or FM-treated animals. There was no significant difference for serum $\mathrm{P}_{4}$ concentration between IP4 and FM during the entire study.

We also compared the serum $\mathrm{P}_{4}$ concentrations in pregnant (Figure 3) and non-pregnant (Figure 4) cows among CON, IP4, CIDR and FM groups. Serum $\mathrm{P}_{4}$ concentrations on $\mathrm{d} 0$ and 6 post AI did not differ $(\mathrm{P}>0.05)$ among treatment groups in pregnant and nonpregnant cows. Similarly, serum $\mathrm{P}_{4}$ concentrations on $\mathrm{d}$ 14,17 and 20 post AI were not significantly different $(\mathrm{P}>0.05)$ among treatment groups in non-pregnant cows. However, in pregnant cows, serum $\mathrm{P}_{4}$ concentrations on $\mathrm{d} 14$ post $\mathrm{AI}$ were greatest $(\mathrm{P}<0.05)$ 
in CIDR group compared to CON, IP4 or FM. Moreover, pregnant cows in IP4 and FM groups had greater $(\mathrm{P}<0.05)$ serum $\mathrm{P}_{4}$ concentrations than pregnant cows in $\mathrm{CON}$ group. However, $\mathrm{P}_{4}$ concentrations did not differ between IP4 and FM groups $(\mathrm{P}<0.05)$. On d 17 post $\mathrm{AI}$, serum $\mathrm{P}_{4}$ concentrations were significantly greater in CIDR group $(\mathrm{P}<0.01)$ compared to $\mathrm{CON}$, IP4 or FM. Interestingly $\mathrm{P}_{4}$ concentrations did not differ between $\mathrm{CON}$ and FM groups. However, pregnant cows in the IP4 group had greater $(\mathrm{P}<0.01) \mathrm{P}_{4}$ concentrations than pregnant cows in the CON group. Cows in the CIDR group also had the greatest serum P4 concentrations on d 20 post $\mathrm{AI}(\mathrm{P}<0.01)$. In addition, cows in FM and IP4 groups had greater $\mathrm{P}_{4}$ concentrations than cows in CON group $(\mathrm{P}<0.01)$. However, serum $\mathrm{P}_{4}$ concentrations did not differ between IP4 and FM groups $(\mathrm{P}>0.05)$.

The P/AI for CON, IP4, CIDR and FM groups were $25 \%(5 / 20), 40 \%(8 / 20), 55 \%(11 / 20)$ and $35 \%$ $(7 / 20)$, respectively. There was a significant difference for $\mathrm{P} / \mathrm{AI}$ between $\mathrm{CIDR}$ and $\mathrm{CON}$ groups $(\mathrm{P}=0.03)$. However, P/AI did not differ between IP4 and FM groups $(\mathrm{P}=0.58)$ or when both groups were compared with $\mathrm{CON}(\mathrm{P}=0.17)$.
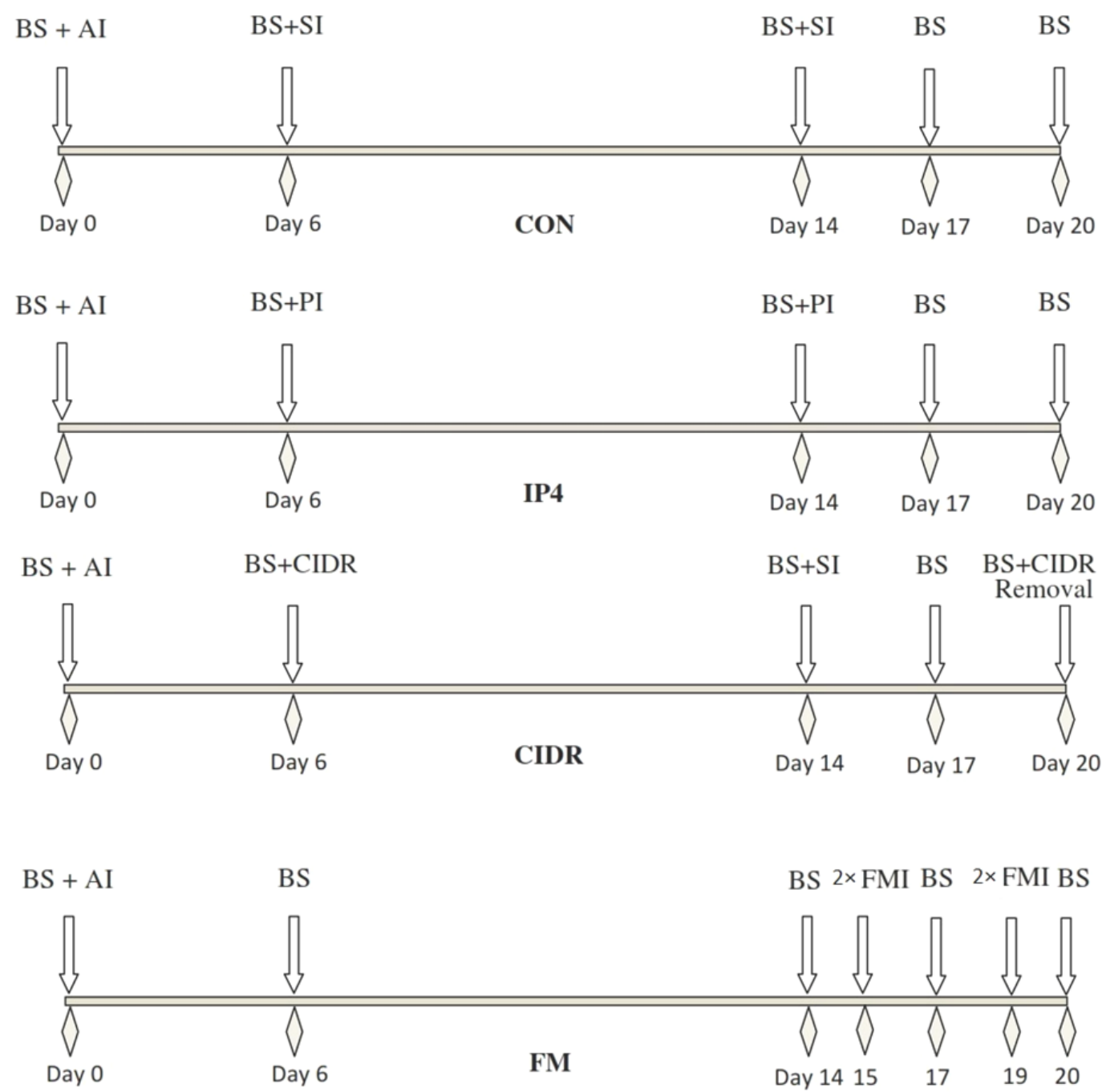

Figure 1. Illustration of experimental procedures and treatments during the study. Lactating dairy cows $(n=80)$ were randomly allocated to one of the following treatments groups: CON (control group: injection of saline on d 6 and 14 post AI); IP4 (injection of $125 \mathrm{mg}$ of progesterone im on $\mathrm{d} 6$ and 14 post AI); CIDR (insertion of a controlled internal drug-release device containing $1.38 \mathrm{~g}$ of P4 from d 6 to 20 post AI) or FM (injection of $0.625 \mathrm{~g}$ of Flunixin Meglumine im twice daily on d 15 and 19 post AI). AI (Artificial Insemination); BS (Blood Sampling); SI (Saline Injection); PI (Progesterone Injection); FM (Flunixin Meglumine). 
Barkhori-Mehni et al. Exogenous Progesterone After AI on Cattle P/AI.

Table 1. Serum progesterone concentrations $(\mathrm{ng} / \mathrm{mL})$ in lactating dairy cows treated with saline (CON), progesterone (IP4), CIDR, or flunixin meglumine (FM).

\begin{tabular}{|c|c|c|c|c|c|c|c|}
\hline Treatments $^{1}$ & & & & & Contra & & \\
\hline Sampling time points & $\mathrm{CON}$ & IP4 & CIDR & FM & $\mathrm{P}$ & $\mathrm{C} 1$ & $\mathrm{C} 2$ \\
\hline $\mathrm{d} \mathrm{0}^{3}$ & & & & & & & \\
\hline Non-Pregnant & $0.221 \pm 0.08$ & $0.238 \pm 0.07$ & $0.263 \pm 0.01$ & $0.213 \pm 0.07$ & 0.93 & 0.71 & 0.80 \\
\hline Pregnant & $0.245 \pm 0.09$ & $0.273 \pm 0.09$ & $0.297 \pm 0.06$ & $0.249 \pm 0.05$ & 0.75 & 0.67 & 0.73 \\
\hline Overall & $0.234 \pm 0.05$ & $0.261 \pm 0.04$ & $0.285 \pm 0.08$ & $0.230 \pm 0.09$ & 0.81 & 0.74 & 0.84 \\
\hline d 6 & & & & & & & \\
\hline Non-Pregnant & $2.11 \pm 0.23$ & $3.09 \pm 0.43$ & $3.78 \pm 0.30$ & $3.19 \pm 0.31$ & 0.36 & 0.27 & 0.23 \\
\hline Pregnant & $2.40 \pm 0.12$ & $3.40 \pm 0.18$ & $4.12 \pm 0.22$ & $3.56 \pm 0.23$ & 0.67 & 0.56 & 0.17 \\
\hline Overall & $2.28 \pm 0.16$ & $3.23 \pm 0.14$ & $3.97 \pm 0.20$ & $3.36 \pm 0.15$ & 0.42 & 0.38 & 0.11 \\
\hline d 14 & & & & & & & \\
\hline Non-Pregnant & $3.91 \pm 0.95$ & $5.01 \pm 1.09$ & $5.29 \pm 0.83$ & $4.18 \pm 0.79$ & 0.12 & 0.23 & 0.13 \\
\hline Pregnant & $4.42 \pm 0.78$ & $5.41 \pm 0.96$ & $8.23 \pm 75$ & $5.12 \pm 0.74$ & 0.05 & 0.06 & 0.03 \\
\hline Overall & $4.23 \pm 0.56$ & $5.23 \pm 0.75$ & $7.12 \pm 0.47$ & $4.85 \pm 0.86$ & 0.06 & 0.08 & 0.09 \\
\hline d 17 & & & & & & & \\
\hline Non-Pregnant & $3.23 \pm 1.09$ & $4.49 \pm 0.45$ & $5.37 \pm 0.62$ & $3.98 \pm 0.57$ & 0.34 & 0.18 & 0.21 \\
\hline Pregnant & $6.42 \pm 95$ & $8.78 \pm 0.73$ & $10.19 \pm 0.48$ & $8.23 \pm 0.97$ & $<0.01$ & 0.02 & $<0.01$ \\
\hline Overall & $5.35 \pm 0.48$ & $7.12 \pm 0.87$ & $9.46 \pm 0.92$ & $6.38 \pm 0.57$ & $<0.01$ & $<0.01$ & $<0.01$ \\
\hline d 20 & & & & & & & \\
\hline Non-Pregnant & $2.34 \pm 0.35$ & $4.98 \pm 0.67$ & $5.19 \pm 0.96$ & $4.79 \pm 0.65$ & 0.24 & 0.36 & 0.42 \\
\hline Pregnant & $7.78 \pm 0.95$ & $11.87 \pm 0.86$ & $13.23 \pm 1.25$ & $9.21 \pm 1.08$ & $<0.01$ & $<0.01$ & $<0.01$ \\
\hline Overall & $5.75 \pm 0.56$ & $8.73 \pm 0.67$ & $9.86 \pm 0.86$ & $7.05 \pm 0.71$ & $<0.01$ & $<0.01$ & 0.02 \\
\hline
\end{tabular}

${ }^{1} \mathrm{CON}$ : injection of saline on d 6 and 14 post AI; IP4: injection of $125 \mathrm{mg}$ of P4 im on d 6 and 14 post AI; CIDR: administration of a controlled internal drug-release insert containing $1.38 \mathrm{~g}$ of P4 from d 6 to 20 post AI; FM: $1.25 \mathrm{~g}$ of Flunixin Meglumine, a non-steroidal anti-inflammatory drug, im twice daily on d 15 and 19 post AI. ${ }^{2}$ Orthogonal contrasts; contrast 1 (C1), FM vs. IP4 and CIDR; and contrast 2 (C2), IP4 vs. CIDR. ${ }^{3}$ day $0=$ day of AI.

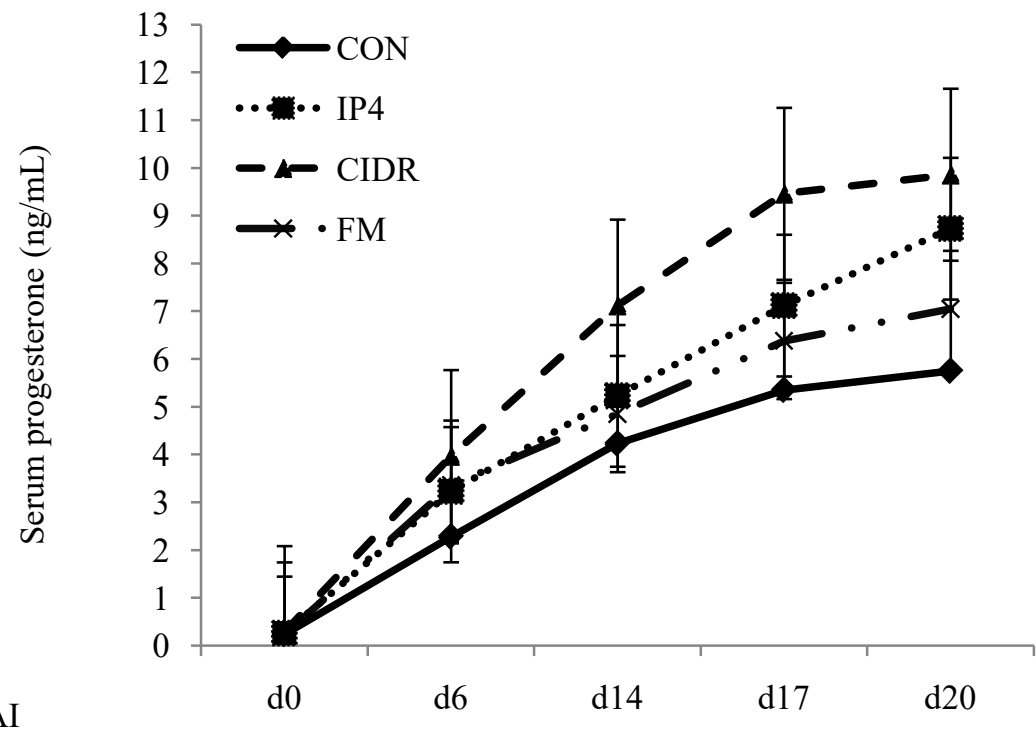

Figure 2. Serum progesterone $\left(\mathrm{P}_{4}\right)$ concentrations $(\mathrm{ng} / \mathrm{mL})$ in all lactating dairy cows during the study. CON $(\diamond)$ : received saline solution im on d 6 and 14 post AI; IP4 ( $\boldsymbol{\square})$ : received $125 \mathrm{mg}$ of $\mathrm{P}_{4}$ im on d 6 and 14 post AI; CIDR $(\mathbf{\Delta})$ : given a controlled internal drug-release device containing $1.38 \mathrm{~g}$ of $\mathrm{P}_{4}$ from $\mathrm{d} 6$ to 20 post AI; FM ( $\times$ ): received $0.625 \mathrm{~g}$ of Flunixin Meglumine (FM), a non-steroidal anti-inflammatory drug, im twice daily on $\mathrm{d} 15$ and 19 post AI. 


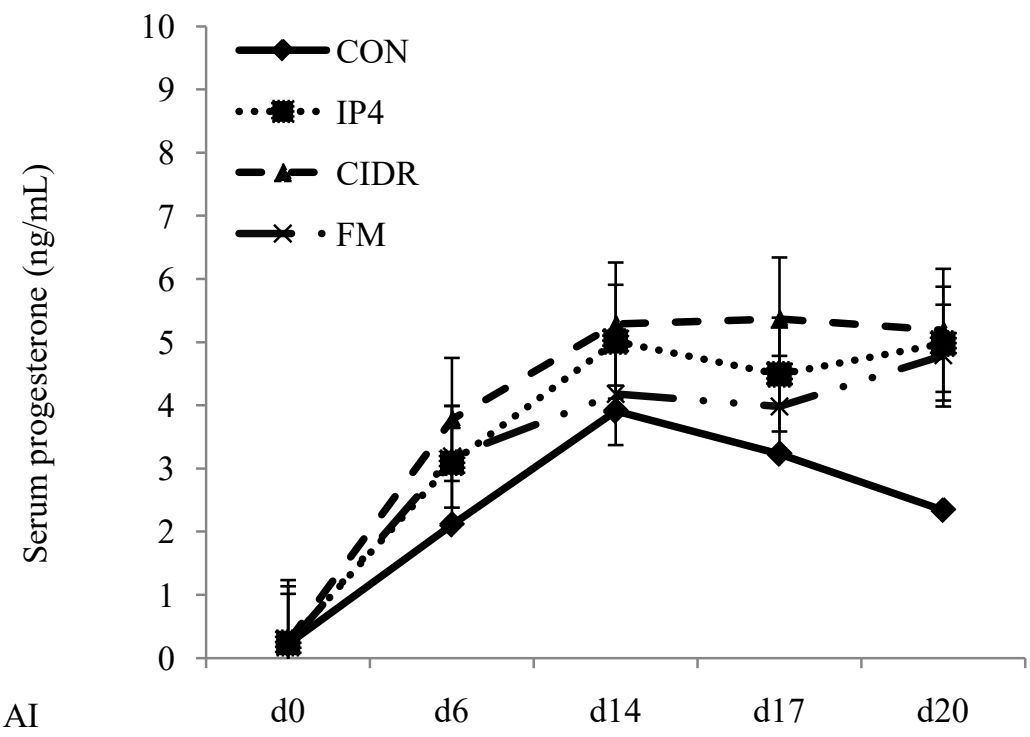

Figure 3. Serum progesterone $\left(\mathrm{P}_{4}\right)$ concentrations $(\mathrm{ng} / \mathrm{mL})$ in non-pregnant lactating dairy cows during the study. CON ( $\diamond$ ): received saline solution im on d 6 and 14 post AI; IP4 (ם): received $125 \mathrm{mg}$ of $\mathrm{P}_{4}$ im on d 6 and 14 post AI; CIDR $(\boldsymbol{\Delta})$ : given a controlled internal drug-release device containing $1.38 \mathrm{~g}$ of $\mathrm{P}_{4}$ from d 6 to 20 post AI; FM $(\times)$ : received $0.625 \mathrm{~g}$ of Flunixin Meglumine (FM), a non-steroidal anti-inflammatory drug, im twice daily on d 15 and 19 post $\mathrm{AI}$.

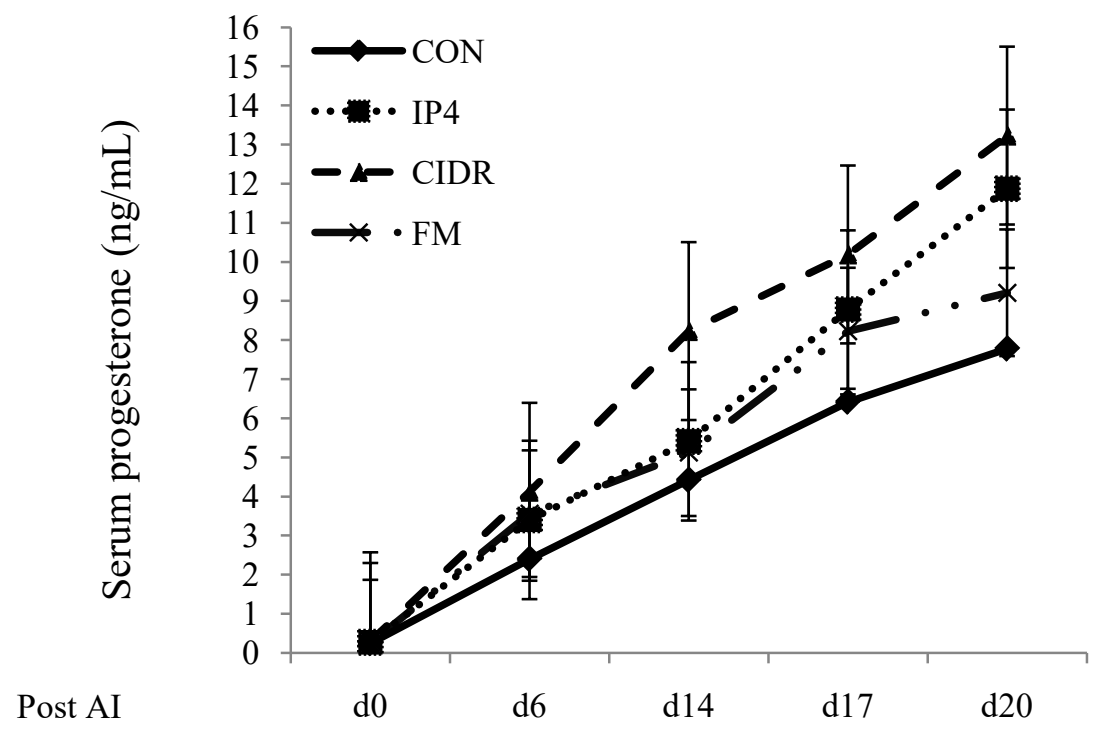

Figure 4. Serum progesterone $\left(\mathrm{P}_{4}\right)$ concentrations $(\mathrm{ng} / \mathrm{mL})$ in pregnant lactating dairy cows during the study. CON (४): received saline solution im on d 6 and 14 post AI; IP4 (a): received $125 \mathrm{mg}$ of $\mathrm{P}_{4}$ im on d 6 and 14 post AI; CIDR ( $\boldsymbol{\Delta})$ : given a controlled internal drug-release device containing $1.38 \mathrm{~g}$ of $\mathrm{P}_{4}$ from d 6 to 20 post AI; FM $(\times)$ : received $0.625 \mathrm{~g}$ of Flunixin Meglumine (FM), a non-steroidal anti-inflammatory drug, im twice daily on d 15 and 19 post AI.

\section{Discussion}

Progesterone is essential to successful establishment of pregnancy in cattle and inadequate circulating $\mathrm{P}_{4}$ is one of the main reasons of low fertility in lactating dairy cows (Inskeep, 2004; Dirandeh et al., 2018). The present study evaluated the effect of post AI administration of exogenous $\mathrm{P}_{4}$ or a $\mathrm{PGF}_{2} \alpha$ synthesis inhibitor agent on serum $\mathrm{P}_{4}$ concentrations in lactating dairy cows. There were no significant differences for serum $\mathrm{P}_{4}$ concentrations among treatment groups on $\mathrm{d} 0$ and 6 post AI in pregnant and non-pregnant cows. This was expected as treatments were initiated on $\mathrm{d} 6$ or after d 6 post AI. However, serum $\mathrm{P}_{4}$ concentrations were affected by treatments on $\mathrm{d} 14,17$ and 20 post AI. Cows given exogenous $\mathrm{P}_{4}$, in particular those receiving a CIDR insert, tended to have greater $\mathrm{P}_{4}$ concentrations on d 14 post AI compared to those receiving FM or control group. On d 17 and 20 , the average serum $\mathrm{P}_{4}$ concentration remained greater in cows given a CIDR insert but it was not statistically different between cows in $\mathrm{IP}_{4}$ and $\mathrm{FM}$ groups. Control cows had lower serum $\mathrm{P}_{4}$ 
concentrations compared to all three treatment groups. The differences in serum $\mathrm{P}_{4}$ concentrations on $\mathrm{d} 20$ post AI between treatment groups and control might have also been associated to the pregnancy status of the cows, rather than merely to the treatment per se, as numerically more cows were pregnant in all three treatment groups compared to control.

The pharmacokinetics of $\mathrm{P}_{4}$ following CIDR insertion has been previously evaluated in cattle (Martinez et al., 2007; Mariano et al., 2010). In a study, ovariectomized beef cows received a previously used CIDR insert for $7 \mathrm{~d}$. Plasma $\mathrm{P}_{4}$ concentrations increased to $\sim 2 \mathrm{ng} / \mathrm{mL}$ by $6 \mathrm{~h}$ after CIDR insertion. Thereafter, plasma $\mathrm{P}_{4}$ concentrations decreased by $84 \mathrm{~h}$ after CIDR insertion and remained relatively constant. By $12 \mathrm{~h}$ after CIDR removal on day $7, \mathrm{P}_{4}$ concentrations declined to $<0.2 \mathrm{ng} / \mathrm{mL}$ (Martinez et al., 2007). In another study using lactating dairy cows without a functional $\mathrm{CL}$, serum $\mathrm{P}_{4}$ peaked within $3 \mathrm{~h}$ after CIDR insertion followed by a progressive decrease over the next $2 \mathrm{~d}$ until reaching sustained concentrations over the remaining $6 \mathrm{~d}$ of CIDR treatment. The range of sustained $\mathrm{P}_{4}$ serum concentrations varied between 2.25 and $4.09 \mathrm{ng} / \mathrm{mL}$ (Mariano et al., 2010). In the present study, serum $\mathrm{P}_{4}$ concentrations increased from $\sim 4$ to $\sim 9$ $\mathrm{ng} / \mathrm{mL}$ by $11 \mathrm{~d}$ after CIDR insertion and remained relatively constant until CIDR removal ( $\mathrm{d} 20$ post $\mathrm{AI})$ in CIDR-treated cows.

Neither the pharmacokinetics of $\mathrm{P}_{4}$ following intramuscular injections nor their effect on serum $\mathrm{P}_{4}$ concentrations and $\mathrm{PR} / \mathrm{AI}$ has been reported in lactating dairy cows. However, Turino et al. (2010) examined the pharmacokinetics of $\mathrm{P}_{4}$ in lactating dairy cows given an intravenous injection of $100 \mathrm{mg} \mathrm{P}_{4}$. Plasma $\mathrm{P}_{4}$ reached a concentration of $140 \mathrm{ng} / \mathrm{mL} 1 \mathrm{~min}$ after treatment and dropped to baseline concentrations within $2 \mathrm{~h}$ after treatment (Turino et al., 2010). In our study, serum $\mathrm{P}_{4}$ concentrations increased from $\sim 3$ (day 6 post $\mathrm{AI}$ ) to $\sim 5$ $\mathrm{ng} / \mathrm{mL}$ (day 14 post $\mathrm{AI}$ ) and from $\sim 5$ (day 14 post $\mathrm{AI}$ ) to $\sim 9 \mathrm{ng} / \mathrm{mL}$ (day 20 post $\mathrm{AI}$ ) in cows given $\mathrm{P} 4 \mathrm{im}$.

Multiple factors can affect the very complex process of pregnancy maintenance during the time of recognition of pregnancy. During implantation, appropriate antiluteolytic signals i.e. interferon-tau produced by conceptus is vital to prevent endometrial $\mathrm{PGF}_{2} \alpha$ secretion (Poyser, 1995; Dirandeh et al., 2015). Conversely, during maternal recognition of pregnancy, interferon-tau increases endometrial prostaglandin $\mathrm{E}_{2}$ $\left(\mathrm{PGE}_{2}\right)$, which is considered a potent luteoprotective factor (Arosh et al., 2016). Interestingly, endometrial $\mathrm{PGE}_{2}$ induces additional $\mathrm{PGE}_{2}$ biosynthesis from CL which counteracts the luteolytic effect of $\mathrm{PGF}_{2} \alpha$ during maternal recognition of pregnancy or at the time of establishment of pregnancy (Romero et al., 2015). Agents that prevent the synthesis of $\mathrm{PGF}_{2} \alpha$ such as Flunixin Meglumine or Meloxicam are licensed to be used in cattle and can potentially extend the CL life span. These agents are classified as non-steroidal antiinflammatory drugs (NSAIDs) which may act on different prostaglandin pathways (i.e. COX-1 and COX2). Flunixin Meglumine is both a COX-1 and COX-2 inhibitor but is more selective for $\mathrm{COX}-1$; it has an elimination half-life of 3 to $8 \mathrm{~h}$ (Odensvik, 1995). In a study, supplementation with $1 \mathrm{~g}$ of FM during the first 6 $\mathrm{d}$ postpartum decreased the release of $\mathrm{PGF}_{2} \alpha$ as mirrored by decreased plasma concentrations of 13, 14dihydro-15-keto- $\mathrm{PGF}_{2} \alpha$ in brown Swiss cows (Guilbault et al., 1987).

The current study also evaluated the effect of post AI administration of exogenous $\mathrm{P}_{4}$ or a $\mathrm{PGF}_{2} \alpha$ synthesis inhibitor agent on $\mathrm{P} / \mathrm{AI}$ in lactating dairy cows. It has been shown that low circulating $\mathrm{P}_{4}$ concentrations or a delay in the rise of $\mathrm{P}_{4}$ during the early post ovulatory phase is associated with reduced conceptus development and fertility in cattle (Mann and Lamming, 1999; Masoumi et al., 2012; Masoumi et al., 2017). Several studies have evaluated the effect of post AI supplementation with exogenous $\mathrm{P}_{4}$ during metaestrus or early diestrus on fertility of lactating dairy cows. Administration of a previously used CIDR, which originally contained $1.9 \mathrm{~g}$ of $\mathrm{P}_{4}$, from day 3.5 to day 10 post AI resulted in improved P/AI of dairy cows (Larson et al., 2007). However, other researchers (Arndt et al., 2009; Colazo et al., 2013) did not observe any improvement in $\mathrm{P} / \mathrm{AI}$ in lactating cows treated with a CIDR containing $1.38 \mathrm{~g}$ of $\mathrm{P}_{4}$ or a PRID containing 1.55 $\mathrm{g} \mathrm{P}_{4}$, from d 4 to 18 or 4.5 to 11.5 post AI, respectively.

A research group from Spain has investigated the effect of $\mathrm{P}_{4}$ supplementation during late diestrus or at the time of maternal recognition of pregnancy on reproductive performance of high producing dairy cows. Circulating concentrations of $\mathrm{P}_{4}$ and fertility did not increase in dairy cows given an insert containing $1.55 \mathrm{~g}$ of $\mathrm{P}_{4}$ from d 5 to 19 post AI (Garcia-Ispierto and LópezGatius, 2012). In a more recent study, Garcia-Ispierto et al. (2016) determined fertility response to $\mathrm{P}_{4}$ supplementation from day 15 to 17 post-AI in highproducing dairy cows. Cows with no history of early postpartum reproductive disorders (i.e. retained placenta) that were supplemented with $\mathrm{P}_{4}$ during maternal recognition of pregnancy were 1.6 times more likely to become pregnant than the control (no $\mathrm{P}_{4}$ treatment) herd mates.

In the present study, P/AI was enhanced in cows given a CIDR insert compared to control cows. Albeit, no statistically significant, P/AI in IP4 cows was $14 \%$ greater than in control cows. It is noteworthy to mention that the effect of $\mathrm{P}_{4}$ on fertility was not the primary objective of this study, which was under powered to detect a $14 \%$ difference in P/AI among treatments. However, our results are in agreement with others and support the notion that $\mathrm{P}_{4}$ supplementation during early and late diestrus has a positive effect on $\mathrm{P} / \mathrm{AI}$ in lactating dairy cows. In addition, numerically more FM cows $(35 \%)$ become pregnant compared to control cows $(25 \%)$, but the difference in P/AI was not statistically significant. Current research has not investigated the effect of administration of FM on P/AI in lactating dairy cows, but several reports have been published regarding the effect of FM on P/AI in dairy heifers. In agreement with our results, dairy heifers $(\mathrm{n}=$ 2325) treated twice with $400 \mathrm{mg}$ of FM im at $\mathrm{d} 15$ and 16 post $\mathrm{AI}$ had similar P/AI compared to untreated heifers (59.4 vs 59.5\%) (Rabaglino et al., 2010). 
However, Guzeloglu et al. (2007) reported that the administration of $1.1 \mathrm{mg} / \mathrm{kg} \mathrm{FM} 12 \mathrm{~h}$ apart at 15.5 and $16 \mathrm{~d}$ after timed-artificial insemination (TAI) improved $\mathrm{P} / \mathrm{AI}$ by $23 \%$ in dairy heifers (69.2 vs $46.2 \%)$. Also, FM has been administered to prevent early regression of the $\mathrm{CL}$ and increase pregnancy rate in recipient cattle immediately before embryo transfer (Schrick et al., 2001; Aguiar et al., 2013; Kasimanickam et al., 2018). Amiridis et al. (2009) assessed the effectiveness of three different NASIDs including ketoprofen, Meloxicam and FM on the length of estrous cycle and showed that Meloxicam was the most potent among the three NAIDs. In addition, Aguiar et al. (2013) reported that Meloxicam had a positive effect on the overall pregnancy rate of embryo recipient heifers. However, pregnancy rate was not affected by administration of Meloxicam recipient heifers classified as Grade I (easy passing catheter) but Meloxicam increased the pregnancy rate of heifers classified as Grade II (difficult passing catheter). Therefore, the effect of the administration of FM or Meloxicam on P/AI in lactating dairy cows warrants further investigation.

\section{Conclusions}

In summary, treatment with exogenous $\mathrm{P}_{4}$ (i.e. CIDR insertion from d 6 to 20 post $\mathrm{AI}$ or $\mathrm{P}_{4}$ injection on d 6 and 14 post AI) or Flunixin Meglumine (PGF2 $\alpha$ synthesis inhibitor; twice daily on d 15 and 19 post AI) increased serum $\mathrm{P}_{4}$ concentrations compared to treatment with saline solution (control). However, results suggest that only CIDR administration would improve $\mathrm{P} / \mathrm{AI}$ in lactating dairy cows.

\section{Acknowledgements}

The authors would like to thank Dr. JeanChristophe Bambou from INRA, France for initial assessment of the manuscript. The authors also acknowledge the considerable contributions and valuable assistance during the study of the managers and staff of Ravansar Dairy Farm.

\section{Conflict of Interest Declaration}

The authors declare that there is no conflict of interest.

\section{References}

Aguiar TS, Araújo CV, Tirloni RR, Martins LR. 2013. Effect of meloxicam on pregnancy rate of recipient heifers following transfer of in vitro produced embryos. Reprod Dom Anim, 48:984-988.

Amiridis GS, Tsiligianni TH, Dovolou E, Rekkas C, Vouzaras D, Menegatos I. 2009. Combined administration of gonadotropin-releasing hormone, progesterone, and meloxicam is an effective treatment for the repeat-breeder cow. Theriogenology, 72:542548.

Anderson K, Kindahl H, Smith A, Davis L, Gustafsson B. 1986. Endotoxin-induced bovine mastitis: arachidonic acid metabolites in milk and plasma and effect of flunixin meglumine. Am J Vet Res, 47:1373-1377.

Arndt WJ, Holle AJ, Bauer ML, Kirsch JD, Schimek DE, Odde KG, Vonnahme KA. 2009. Effect of postinsemination progesterone supplementation on pregnancy rate in dairy cows. Can J Vet Res, 73:271.

Arosh JA, Banu SK, McCracken JA. 2016. Novel concepts on the role of prostaglandins on luteal maintenance and maternal recognition and establishment of pregnancy in ruminants. $J$ Dairy $S c i$, 99:5926-5940.

Badiei A, Aliverdilou A, Amanlou H, Beheshti M, Dirandeh E, Masoumi R. Moosakhani F, Petit HV. 2014. Postpartum responses of dairy cows supplemented with n-3 fatty acids for different durations during the peripartal period. J Dairy Sci, 97:6391-6399.

Colazo MG, Dourey A, Rajamahendran R, Ambrose DJ. 2013. Progesterone supplementation before timed AI increased ovulation synchrony and pregnancy per $\mathrm{AI}$, and supplementation after timed AI reduced pregnancy losses in lactating dairy cows. Theriogenology, 79:833-841.

Dirandeh E, Towhidi A, Ansari Z, Saberifar T, Akhlaghi A, Rezaei Roodbari A. 2015. The endometrial expression of prostaglandin cascade components in lactating dairy cows fed different polyunsaturated fatty acids. Theriogenology, 83:206-212.

Dirandeh E, Masoumi R, Didarkhah M, Samadian F, Dadashpour Davachi N, Colazo MG. 2018. Effect of presynchronization prior to Ovsynch on ovulatory response to first $\mathrm{GnRH}$, ovulatory follicle diameter and pregnancy per AI in multiparous Holstein cows during summer in Iran. Ann Anim Sci, DOI: https://doi.org/10.2478/aoas-2018-0011

Elli M, Gaffuri B, Frigerio A, Zanardelli M, Covini D, Candiani M, Vignali M. 2001. Effect of a single dose of ibuprofen lysinate before embryo transfer on pregnancy rates in cows. Reproduction, 121:151-154.

Friedman E, Roth Z, Voet H, Lavon Y, Wolfenson D. 2012. Progesterone supplementation post insemination improves fertility of cooled dairy cows during the summer. J Dairy Sci, 95:3092-3099.

Garcia-Ispierto I, López-Gatius F. 2012. Effects of GnRH or progesterone treatment on day 5 post AI on plasma progesterone, luteal blood flow and leucocyte counts during the luteal phase in dairy cows. Reprod Domest Anim, 47:224-229.

Garcia-Ispierto I, López-Helguera I, Serrano-Pérez B, Paso V, Tuono T, Ramon A, Mur-Novales R, Tutusaus J, López-Gatius F. 2016. Progesterone supplementation during the time of pregnancy recognition after artificial insemination improves conception rates in high-producing dairy cows. Theriogenology, 85:1343-1347.

Garcia-Ispierto I, López-Gatius F. 2017. Progesterone supplementation in the early luteal phase after artificial insemination improves conception rates in highproducing dairy cows. Theriogenology, 90:20-24.

Geary T, Ansotegui R, MacNeil M, Roberts A, Waterman R. 2010. Effects of flunixin meglumine on pregnancy establishment in beef cattle. J Anim Sci, 


\section{8:943-949.}

Guilbault L, Thatcher W, Drost M, Haibel G. 1987. Influence of a physiological infusion of prostaglandin F $2 \alpha$ into postpartum cows with partially suppressed endogenous production of prostaglandins. 1. Uterine and ovarian morphological responses. Theriogenology, 27:931-946.

Guzeloglu A, Erdem H, Saribay M, Thatcher W, Tekeli T. 2007. Effect of the administration of flunixin meglumine on pregnancy rates in Holstein heifers. Papers \& Articles. Vet Rec, 160:404-406.

Heidari F, Dirandeh E, Pirsaraei ZA, Colazo MG. 2017. Modifications of the G6G timed-AI protocol improved pregnancy per AI and reduced pregnancy loss in lactating dairy cows. Animal, 11:2002-2009.

Holter J, West J, McGilliard M. 1997. Predicting ad libitum dry matter intake and yield of Holstein cows. $J$ Dairy Sci, 80:2188-2199.

Inskeep E. 2004. Preovulatory, postovulatory, and postmaternal recognition effects of concentrations of progesterone on embryonic survival in the cow. J Anim Sci, 82 E-Suppl: E24-39.

Kasimanickam RK, Hall JB, Estill CT, Kastelic JP, Joseph C, Aziz RA, Nak D. 2018. Flunixin meglumine improves pregnancy rate in embryo recipient beef cows with an excitable temperament. Theriogenology, 107:70-77.

Larson SF, Butler W, Currie WB. 2007. Pregnancy rates in lactating dairy cattle following supplementation of progesterone after artificial insemination. Anim Reprod Sci, 102:172-179.

Leroy J, Opsomer G, Van Soom A, Goovaerts I, Bols P. 2008. Reduced fertility in high yielding dairy cows: Are the oocyte and embryo in danger? Part I the importance of negative energy balance and altered corpus luteum function to the reduction of oocyte and embryo quality in high-yielding dairy cows. Reprod Domest Anim, 43:612-622.

López-Gatius F, Camón-Urgel J. 1991. Confirmation of estrus rates by palpation per rectum of genital organs in normal repeat dairy cows. Transbound Emerg Dis, 38:553-556.

Mann G, Lamming G. 1999. The influence of progesterone during early pregnancy in cattle. Reprod Domest Anim, 34:269-274.

Mariano RN, Turino LN, Cabrera MI, Scándolo DE, Maciel MG, Grau RJ. 2010. A simple pharmacokinetic model linking plasma progesterone concentrations with the hormone released from bovine intravaginal inserts. Res Vet Sci, 89:250-256.

Martinez MF, Kastelic JP, Colazo MG, Mapletoft RJ. 2007. Effects of estradiol on gonadotrophin release, estrus and ovulation in CIDR-treated beef cattle. Domest Anim Endocrinol, 33:77-90.

Masoumi R, Towhidi A, Javaremi AN, Nabizadeh H, Zhandi M. 2011. Influence of PGF2 alpha on semen quality and libido in Holstein bulls. Turk J Vet Anim Sci, 35:1-6.

Masoumi R, Badiei A, Imam G, Mosakhani F. Curtis A. 2012. Evaluation of uterotonic effects of Dinoprost in pyometric and clinically healthy lactating dairy cows. Reprod Domest Anim, 47:477.
Masoumi R, Badiei A, Shahneh A, Kohram H, Dirandeh E, Colazo MG. 2017. A short presynchronization with PGF2 $\alpha$ and GnRH improves ovarian response and fertility in lactating Holstein cows subjected to a Heatsynch protocol. Ann Anim Sci, 17:169-177.

Masoumi R, Badiei A, Mousakhani F, Dirandeh E, Zhandi M, Stear M. 2018. Quantification of the uterine involution and dimensions, hormonal response and reproductive performance of pyometric and healthy dairy cows treated with Dinoprost. S Afr J Anim Sci, 48:222-233.

McCracken JA, Custer EE, Lamsa JC. 1999. Luteolysis: a neuroendocrine-mediated event. Physiol Rev, 79:263-323.

Motavalli T, Dirandeh E, Deldar H, Colazo MG. 2017. Evaluation of shortened timed-AI protocols for resynchronization of ovulation in multiparous Holstein dairy cows. Theriogenology, 95:187-192.

Odensvik K. 1995. Pharmacokinetics of flunixin and its effect on prostaglandin F2 $\alpha$ metabolite concentrations after oral and intravenous administration in heifers. $J$ Vet Pharmacol Ther, 18:254-259.

Poyser N. 1995. The control of prostaglandin production by the endometrium in relation to luteolysis and menstruation. Prostag Leukotr Ess, 53:147-195.

Purcell S, Beal W, Gray K. 2005. Effect of a CIDR insert and flunixin meglumine, administered at the time of embryo transfer, on pregnancy rate and resynchronization of estrus in beef cattle. Theriogenology, 64:867-878.

Rabaglino M, Risco C, Thatcher M-J, Lima F, Santos J, Thatcher W. 2010. Use of a five-day progesterone-based timed AI protocol to determine if flunixin meglumine improves pregnancy per timed AI in dairy heifers. Theriogenology, 73:1311-1318.

Romero JJ, Antoniazzi AQ, Nett TM, Ashley RL, Webb BT, Smirnova NP, Bott RC, Bruemmer JE, Bazer FW, Anthony RV, Hansen TR. 2015. Temporal release, paracrine and endocrine actions of ovine conceptus-derived interferon-tau during early pregnancy. Biol Reprod, 93:1-10.

Sangsritavong S, Combs D, Sartori R, Armentano L, Wiltbank M. 2002. High feed intake increases liver blood flow and metabolism of progesterone and estradiol-17 $\beta$ in dairy cattle. J Dairy Sci, 85:2831-2842.

Santos J, Thatcher W, Chebel R, Cerri R, Galvao K. 2004. The effect of embryonic death rates in cattle on the efficacy of estrus synchronization programs. Anim Reprod Sci, 82:513-535.

Schrick F, Hockett M, Towns T, Saxton A, Wert N, Wehrman M. 2001. Administration of a prostaglandin inhibitor immediately prior to embryo transfer improves pregnancy rates in cattle. Theriogenology, 55:370.

Turino LN, Mariano RN, Cabrera MI, Scándolo DE, Maciel MG, Grau RJ. 2010. Pharmacokinetics of progesterone in lactating dairy cows: Gaining some insights into the metabolism from kinetic modeling. $J$ Dairy Sci, 93(3):988-999.

Yan L, Robinson R, Shi Z, Mann G. 2016. Efficacy of progesterone supplementation during early pregnancy in cows: A meta-analysis. Theriogenology, 85:1390-1398. 